\title{
MANAGEMENT ROLES IN POLITICAL AND SENIOR CIVIL SERVANT POSITIONS: A MULTILE-STUDY APPROACH
}

\author{
CARLOS LOSADA \\ ESADE Business School - Ramon Llull University \\ Email: carlos.losada@esade.edu
}

\section{MARC ESTEVE}

School of Public Policy, University College London

\& ESADE Business School - Ramon Llull University

Address: The Rubin Building, 29/30 Tavistock Square, London, UK

Telephone: +020 76794726

Email: marc.esteve@ucl.ac.uk 
A recent trend in public administration studies has begun to assess how public management is performed by politicians and top civil servants. Surprisingly, little is known about how these different posts develop their management roles. Following seminal management studies, we focus on core management roles to compare the ways in which politicians and top civil servants develop their management responsibilities within public organisations. Empirical evidence is provided by triangulating three separate studies developed in Spain. Results from the triangulation show that there is unmistakable evidence of differentiations between politicians and top civil servants when performing their managerial roles.

Key Words: Management roles, contingency approach, politicians, senior civil servants, triangulation. 


\section{MANAGEMENT ROLES IN POLITICAL AND SENIOR CIVIL SERVANT POSITIONS:}

\section{A MULTIPLE-STUDY APPROACH}

Since the early years of public administration studies (when the influential works of Max Weber and Woodrow Wilson started a long and fruitful debate) the relationship between politics and administration has been a relevant issue and remains so today, as many public services are managed in tandem by politicians and senior civil servants (Thompson, 1979; Klausen and Magnier, 1998; Svara, 1999, 2001, 2006; Mouritzen and Svara, 2002; Jacobsen, 2006; Demir and Nyhan, 2008). In the 1980s, reflections on the singular features of the managerial role in the public sector were the subject of many analyses (Allan, 1981; Kurke and Aldrich, 1983; Noordegraaf, 2000; Pavett and Lau, 1980; Rainey, 1989); while more recently, analysis of the public management role has focused extensively on comparing public versus private managers (Hansen and Villadsen, 2010; Nutt, 2006; Pool et al., 2006; Mort et al., 2003).

A second major research trend has focused on the tensions between top bureaucrats and politicians (Aberbach and Rockman, 2006; Christensen and Lægreid, 2012). Among this extensive literature, a few studies have related these tensions to managerial roles (Ammons and Newell, 1989; Bäck, Heinelt and Magnier, 2006; Eskridge, 2014; Klausen and Magnier, 1998; Mouritzen and Svara, 2002). Despite the importance of this topic, there is little empirical evidence about how managerial roles are performed in political positions and top civil servant positions when both are acting as managers, that is, responsible for a unit (ministry, secretary, department, etc.) (Ammons and Newell, 1989; Eskridge, 2014). While not 
many studies have empirically addressed this question, some authors have argued that the management roles held by politicians and top civil servants might differ (Liguori, Sicilia and Steccolini, 2009; May and Winter, 2009). From a purely organisational standpoint there is no difference between them. Both posts are managerial, and some report to others, as in any organisation. Indeed, some scholars and practitioners consider most posts as being part of the 'New Public Management', which denies that there is any real difference between the political management function (PMF) and the civil service management function (CSMF) (Mussari, 1994).

There are a lot of caveats when analysing differences between CSMF and PMF. Klausen and Magnier (1998) differentiate politicians and civil servants as political and classical bureaucrats. They argue that political bureaucrats are closer to policy formulation, while their classical counterparts focus on the administration of public resources to implement a specific public policy. Also, the differentiation between top politicians and top civil servants is difficult and can change according to the country of study (see Klausen and Magnier, 1998 for evidence on institutional differences across western governments).

Our research aims to study how the management role is performed in different sorts of posts within the public sector and explore the consequences. More specifically, we aim to identify the differences and similarities between the management function performed in politically-appointed positions (PMF) and the management function performed in civil servant positions (CSMF).

We take a multiple-study empirical approach using three different research methods (direct observation, interviews and a survey questionnaire), subsequently triangulating the data and testing four hypotheses. The three studies were conducted in Spain where there is a clear distinction between political and non-political 
appointments to public sector organisations. To ensure that our results are comparable with other national contexts, we follow the criteria used by other authors (e.g. Liguori, Sicilia and Steccolini, 2009) and divide our sample into political appointees (to whom we refer as 'politicians') and non-political appointees ('senior civil servants').

\section{Management Roles of Politicians and Top Civil Servants}

We use Mintzberg's $(1973,1989,1994,2009)$ seminal work on the roles that are performed in every managerial position in order to understand the similarities and differences between the management function of politicians and senior civil servants. Mintzberg's work has been widely used to understand how individuals administer organisations (Konrad et al., 2001; Mount and Barlett, 1999; Pavett and Lau, 1983).

In a similar vein, other authors have also considered the different roles developed by politicians and civil servants. One outstanding example is the study by Aberbach et al. (1981) in which the authors identify politicians' and senior civil servants' perceptions of the political role. Both types of managers feel the role of the PMF is to draft policy, represent and respond to certain interests, defend ideological causes and values, and so on. In addition to their role as actors in public policy, politicians also spend a lot of time electioneering and doing party work, redefining fields of political action, drawing up game plans and dealing with the media. But it is important to note that the sample used by Aberbach et al. (1981) consisted of parliamentarians and not politicians in charge of ministries or other elements of the governmental executive branch.

Arguably the tendency of the PMF to give public organisation a political slant, in terms of values and interests, involves deciding which problems should be approached and defining them in an intense process of interaction with other actors. 
Going back to Minzberg's taxonomy, all this may lead to accentuating the managerial role as external leader, spokesperson and innovator (expressed through new visions of public policies, redesigned programmes or simply different ways of doing things).

Politicians are used to articulating and defending their interests in a conflict-ridden work climate. This is noteworthy because they have a tendency to cover broad, poorly organised interests that can usually only be defended by overcoming departmental barriers. Aberbach et al. (1981) consider that both parliamentary politicians and senior civil servants perform the role of facilitator or defender of interests, but not in the same way.

In analysing the kinds of problems that should be addressed by public management, Kammerer's (1964) study stressed its highly ambiguous nature, technical features and interorganisational problems. In this same line of reasoning, Metcalfe (1993) states that 'especially in the higher levels [of public organizations], management ... is a process of interorganizational negotiation aimed to construct, maintain and modify the precarious relations on which both the results of the organizations taken individually and the success of public policy depend' (Metcalfe, 1993:4). The consequence of the interorganisational nature of public problems should be a greater need for a liaison role. This in turn strongly implies an increased need for negotiators and spokespersons. In his observations of public managers employed by the Canadian park service, Mintzberg (1997) found that the director general put great emphasis on networking and spokesperson roles outside the organisation. Mintzberg added internal control and leadership roles to these external roles.

From their different perspectives, these authors describe what the political science literature terms 'political leadership' which is understood as an external role. Most 
management experts consider leadership to be an internal role. This difference goes unnoticed when comparing the political science literature (Heifetz, 1995; Losada, 2008) and private management literature (Badaracco, 2002; Kotter, 1988, 1999; Mintzberg, 1973, 1994, 2009; Sayles, 1993). This kind of 'political leadership' apparently goes a long way towards explaining the difference between senior managers in the private and public sectors and, to a lesser extent, the difference between political and civil service appointees. Furthermore, public management requires much more development and a constant review of broad and complex conceptual frameworks if the outside world is to be understood and changed. Mintzberg (1994) describes this as the 'conceiving role'. The reasons for this may be: the multitude of actors involved in the decision-making process (execution and control); complex interaction between actors; political visibility; lack of any direct relationship between good management and more/better resources; lack of any direct relationship between meeting objectives and organizational continuity and survival; and the nature of public problems. Metcalfe (1993) maintains that public leaders have to approach politics creatively. In other words, they should develop new visions and values from which future objectives, strategies and measures for dealing with social problems will spring. This type of activity involves intense organisational and interorganisational learning, which enables political managers to constantly redesign conceptual frameworks, thus facilitating the development of their policies. Metcalfe states that "public management is more about designing than about managing, the constant design and re-design of systems that are adaptable to public problems is crucial' (1993:26).

Certain management roles crop up repeatedly and follow the original classification proposed by Mintzberg (1989): information, interpersonal and action-decision roles. 
We chose to look at those roles most cited in the literature, and accordingly we select one role from each of these three categories. For information roles, we focus on the spokesperson (external disseminator); for interpersonal roles, we look at liaison; to understand action-decision roles, we focus on external leaders. We also included the conceptualiser role to help us gather a more comprehensive profile of the management styles of both PMF and CSMF posts. Accordingly, we test the following hypotheses:

Hypothesis 1: The liaison role carries greater weight (in terms of time spent on it and importance) for the PMF than the CSMF.

Hypothesis 2: The spokesperson role (external disseminator) carries greater weight (in terms of time spent on it and importance) for the PMF than $r$ the CSMF.

Hypothesis 3. The external leader role carries greater weight (in terms of time spent on it and importance) for the PMF than the CSMF.

Hypothesis 4. The conceptualiser role is of greater weight (in terms of time spent on it and importance) for the PMF than the CSMF.

\section{Methods}

Data triangulation enhances the validity of the findings when studying a specific phenomenon, as multiple viewpoints allow for greater accuracy (Jick, 1979). Following Denzin (1978), we triangulated our findings by using different data sources and implementing different research methods: direct observation, interviews and a questionnaire.

To pinpoint the differences between PMF and CSMF, for each of the three different samples we identified civil servants and politicians from those parts of the executive branch that clearly allow the identification of difference in management roles. Aberbach, Putman and Rockman (1981) identify four images that reflect the 
different combinations of political and administrative functions. In this article we focus on what they call the first image, that is, institutions wherein the roles and responsibilities of politicians and public administrators clearly differ. These samples show a 'strict bifurcation between policy making and administration' (Aberchbach and Rockman, 1988:2). Our criterion when choosing our three study samples was that the managerial posts had to be similar enough to be comparable but also present definite differences. Accordingly, the three studies look at different levels of the Spanish administration - local, regional and national - as well as different geographical areas in Spain.

\section{The distinction between PMF and CSMF in the Spanish System}

Before describing the studies, we should explain first how the PMF and CSMF are formally distinguished in the Spanish Public Administration system. In the case of Spain, which has an institutional design similar to those found in other western democracies, the relationship between politics and administration involves two basic features: first, the public administration is subordinate to the government in accordance with Article 97 of the Spanish Constitution. Secondly, Article 103 characterises public administration, both objectively and subjectively, as having a certain degree of independence from the government by making it directly subordinate to laws and rights, signifying clear constraints on the nation's executive power (Garrido Falla, 1980).

Within this design there are two kinds of operating logic that frequently clash: on the one hand, government function whose legitimacy is based on winning the general election (i.e. the popular sovereignty argument), and on the other, an administration that "cloaks itself in institutional garb" (in the sense meant by Hauriou, in Garrido Falla, 1980:1028). That is, an organisation that appropriates the goals it pursues, and 
draws strength and regulates itself by establishing its own standards of operation. These two logics underlie the tension characterising the relationships between government and administration, which is also the framework of relations between the PMF and the CSMF, analysed in this study.

This tension is dear to the Constitution which submits the administration not only to the rule of law, but also to the imperatives of objectivity and impartiality, two conditions the Constitution does not mention when referring to the government. Public managers tend to move "in a zone where the waters of politics and of the Administration flow together and it is no simple matter to make a clean separation between them". As has been said, "it is not so much a no man's land as an everyman's land, where it is not easy to determine which "script" corresponds to the Government as an organ of political management, and which to the Administration in serving the general interest" (Barcelona, 1991:2364).

Arguably, disputes arising from this tension should ultimately be settled in favour of the government, given its political legitimacy, so long as it remains within the limits imposed by legislation. This implies that such tension is a natural feature of the working climate within public administration, particularly with regard to public managers. On this point, Barcelona cites an interesting opinion tendered by Guaita Martorell which, while it does not clarify the division between politics and administration, accurately describes the true state of affairs "... Article 97 of the Constitution made a good choice in treating the Government and the Administration for what they are ... [a continuum] because while it is true that the Government is outside and above the Administration ... it is also true that it forms an integral part of the Administration it directs, that it constitutes its head and, obviously, is author of the most important administrative acts" (Barcelona, 1991:2364). 


\section{Study 1: Direct observation (semi-structured/shadowing) of high-ranking members of the Catalan Government, city mayors and council members.}

Our first study applies direct observation techniques. The terms 'semi-structured' and shadowing refer to two aspects of direct observation which set it apart from other techniques: on the one hand, it is semi-structured because it is not merely based on filling in forms on which data are determined; nevertheless, the technique is open to incorporation of unexpected behaviour patterns (Steward, 1988). On the other, the method tends to record managers' actions minute by minute. Direct observation is also characterised by other features which have been incorporated in this research. From the viewpoint of the type of unit observed, this research is based on complete behaviour patterns rather than a detailed analysis of individual movements. It is based on a social definition of the observed behaviour (telephone conversation, planned meeting, etc.). Direct observation is both quantitative and qualitative. It is quantitative insofar as it concerns itself with the frequency with which certain kinds of behaviour occur, and qualitative insofar as it covers the search for new features of managers' work in order to build new models (Bailey, 1994). Our objectives in using direct observation are to both describe and interpret behavioural patterns (managerial roles) (Riba, 1993). The units of observation chosen in the (partially) deductive parts of this study were based on previous theoretical work. By contrast, the inductive part of the observation was limited to the detailed recording of events and their grouping by similarities, according to topographic, functional and procedural criteria.

Sample: We contacted senior politicians and civil servant managers at national (Government of Catalonia), and local level (several City Councils). Direct observation is tough on the person studied. In all cases, the aim was to spend as much 
time as possible with the manager on the chosen days. Managers have no secrets or privacy during observation, something which made it difficult to randomly obtain candidates for observation. We were able to secure 12 senior politicians and civil servant managers who were prepared to be placed under observation for an entire day. The sample was formed of two mayors; two government ministers, four political appointments at secretary level and four senior civil servants. This sample size is sufficiently large to permit quite wide-ranging comparisons. The sample size in comparable studies ranges between two and 10 (see, for example, Duignan, 1980; Feilders, 1979; Kaplan, 1998; Mintzberg, 1973; Pitner, 1978; Snyder and Glueck, 1980). The sample was developed in order to study the differences between the two kinds of posts. Accordingly, we placed more emphasis on observing posts in which the parameters changed (the only constant being the civil service or political natures of the post).

Duration and Protocol of the Observation: Each politician and senior civil servant was observed for an entire day. In total, we recorded 127 hours of direct observation. The procedures for determining the observation day were varied. Usually, we made a telephone call to the subject, explaining what the research involved and what would be required of the person observed. Subjects were told that the research would involve their activity being shadowed throughout an entire working day. An appointment was then made with the subject's assistant. The choice of day could constitute a possible source of bias. Subjects might choose a particular day or change their schedule on the day selected for observation in order to avoid situations involving conflict or embarrassment or, conversely, showcase situations that might make them appear more capable and powerful than they really are. We took a number of steps to minimise the risk of this kind of bias. First, we explicitly requested a 
'typical' or 'average' working day. Second, on some occasions we changed the day (for various reasons), giving subjects very little time to change their agenda, as we requested an alternative observation session for the very next day; we profited from our awareness that it is virtually impossible for senior managers to change their agendas at whim; the subjects had limited scope to change their agendas on the observation day, even supposing they had wanted to. Third, we asked for a very specific day, instead of leaving the decision to them.

An initial meeting took place on a day preceding the observation. This interview was particularly important in cases where the researcher was unfamiliar with the posts to be observed (e.g. mayors). Before the observation day, we needed to discover the contingency variables of the subject's post, its competencies, the organisation of the unit, the people around the subject (subordinates and others) and current critical concerns. We also obtained as much information as possible about variables relating to the subject: age, education, previous experience, etc. In some cases, this information could only be gathered after observation. Observation was highly intensive. From the start, everything observed was described in such detail as if they were being filmed (e.g. 'manager goes to secretary's desk') and all conversations noted (e.g. 'Put me through to the tax director'). Several weeks later, the behaviour observations were coded and categorised into the set of managerial roles.

Behavioural Units: In direct observation methods, the researcher observes a constant flow of activities in which parallel processes occasionally overlap. In order to make sense of the situation being observed, the researcher must create behavioural or observational units. Behavioural units should be determined in accordance with: a) the nature of observed behavioural patterns (work and social ones in this case); $b$ ) the parameters employed for categorising behaviour; $c$ ) the specific ends of the 
research, which differ depending on whether the study is of a deductive or inductive nature (Anguera, 1993). The observational technique attempts to establish highlydetailed behavioural units, grouping these according to various criteria and providing breakdowns of categories as appropriate. The behavioural units are chosen to establish whether or not the hypotheses are true. This kind of observation is both more selective and wide-reaching given that it focuses on behavioural observations directly related to the initial hypotheses. However, the technique also tries to faithfully record all observations given that these may inductively yield new ideas not originally contemplated.

An unresolved matter of debate concerns which behavioural units should be used to study the manager's function: actions (e.g. reading), activities (e.g. discussing a subject with a subordinate), roles (e.g. resolving conflicts), and functions (e.g. conserving assets). In fact, the difference between these categories is not clear in the writings of various authors (see, for example, Hales, 1986; Martinko and Gardner, 1990). However, as mentioned above, in this case we need to address our attention to units of behaviour rather than minute details (Anguera, 1993). This decision is strongly influenced by the questions to be answered, in our case with the hypotheses set out earlier. Hence, the choice of natural, functional units of behaviour; these behavioural patterns make organisational sense in themselves (e.g. making a telephone call or answering an e-mail). Details below a strictly natural, functional behaviour threshold were discarded (i.e. typing a letter, picking up a telephone receiver, etc.) since they were irrelevant for the purposes of this study.

Categorisation: Categorisation involves splitting behavioural units into logical categories. A category exists when two or more events are treated in the same way (Mervis and Pani, 1980). A category 
"is the result of a series of cognitive operations which leads to the establishment of classes linked by complementary relationships. These classes are established in accordance with a criterion chosen for the purpose. Items within a class exhibit the same essential features even though the form they take may differ significantly" (Anguera, 1993:120).

Categorisation allows for a move from initial observations and impressions to systematic, quantitative analysis in which findings can be verified by other researchers. The process is based on theory, which usually requires a previous exploratory phase. The problem of classifying managers' behaviour is that it is multidimensional by its very nature, thus requiring various sets of categories.

It is important that each category provides as much information as possible and is in tune with reality. The categorisation scheme must meet the following characteristics: exhaustiveness (any kind of behaviour must be assignable to a category) and mutual exclusiveness (no overlap in categories) (Sierra, 1994). However, the second characteristic is not applicable to this research given that a particular behavioural unit can simultaneously play several roles. Such mutual exclusiveness is neither possible nor desirable in this study (Brownell, 1978). For example, it is common for monitoring, supervisory and leadership functions to be performed at the same time in, say, a meeting or in informal discussion. In addition, we must accept a certain fuzziness in category boundaries (Anguera, 1993). Each category has a certain quintessential nature (which usually underlie the criteria for grouping similar items) and a certain flexibility and open-endedness (i.e. an apparent heterogeneity) (Anguera, 1993). Following earlier published work (Mintzberg, 1973; Martinko and Gardner, 1990), we relied on a final subset of topographic categories, such as contact method, who initiated the observed activity, participants, place, type 
of document worked on, sender, attention paid, action taken; and also functional categories, including manager's roles such as conceptualiser, monitoring, internal disseminator, external disseminator, direct supervision, etc.

Analysis: Data was gathered and the analysis conducted in two stages: first, during the observation, the researcher filled a categorisation table (see Exhibit 1 for an example) with each of the observed behaviours developed by the politician or the civil servant manager under study. The second stage was carried out at the end of each session and consisted of writing up the notes of those actions considered to be relevant for the topic under study. This was an inductive process that allowed us to make sense of the evidence collected during the shadowing sessions.

[-Insert Exhibit 1 about here-]

\section{Study 2: Interviewing high-ranking members across Spanish public administration: Central, Regional and Local Governments}

The second study was conducted through interviews for two reasons. First, we needed to offset the limitations of a small sample in direct observation methodology which permits a deeper understanding of the conclusions reached. Second, we wanted to capture new dimensions of a phenomenon and view it from a different methodological perspective. Our aim was to reveal singular features not observed in the PMF or CSMF and the causes of those features (Mason, 1996).

We adopted a mixed interview approach in which closed and open-ended questions were combined (Visauta, 1989). A semi-structured, rather than in-depth, interview was chosen since our intention was to observe actual differences in very specific matters, not individual perceptions (Creswell, 2013). A semi-structured interview also allows for flexibility, as it covers all the relevant items but facilitates the possibility of additional information emerging. We adopted an open, informal 
approach in the interviews to encourage managers to comment freely. This helped to pinpoint differences and their causes, and enhanced the quality of information provided.

Sample: The individuals chosen to participate in the study were people with considerable experience in both political and civil service posts. Managers' careers were reviewed in order to select two posts (political and civil service) held by respondents during their careers for comparison purposes. The sample was purposive, as we intended to find individuals with a high degree of experience and knowledge in the topic of study. In this sense, we followed the recommendations of Eisenhard and Graebner (2007:27) to find a sample that is "suitable for illuminating and extending relationships and logic among construct", rather than trying to find a sample that could help us to generalise the results of the study.

Three channels were used to obtain potential candidates for interview. The first one was the Catalan government's computerised system of staff records (GIP-SIP) to discover which civil servants had occupied political posts. Unfortunately, very few records were found (just four cases): this was not only because there were relatively few cases in proportion to the total number of Civil Service managers but also because the data in the system was very recent. There was no possibility of conducting a similar systematic search in local administration and other regional governments at the time. Accordingly, this initial strategy was complemented with a snowball approach to gather more interviewees. On conclusion of the interview, the manager was asked if they knew of any similar cases. Lastly, managers who had held personnel management posts in public administration (Director General of State Public Administration, personnel directors, etc.) were also contacted and requested to provide cases. The candidates identified were then contacted and an interview held 
in accordance with our interview script ${ }^{1}$. Only three of the contacted individuals refused to take part in the study.

Three factors determined the final choice of interview candidates: representativeness of political and civil service posts, accessibility, and contingency variables. The most important characteristic of the sample is that each participant had to hold at least five years of working experience both as a senior public manager and also as a politician. The interviewees were also classified according to ideological persuasion (nationalist/non-nationalist; left/right/centre). This classification was performed retrospectively in the light of the researcher's knowledge of the interviewee. This was undertaken to ensure that all kinds of political sensitivity were included in the sample. Finally, 33 semi-structured interviews were developed, covering several geographical regions of Spain and three administrative levels (federal/central; state/regional level and local). Table 1 provides the post characteristics of all interviewees who finally took part in the study.

[-Insert table 1 about here-]

Procedure of the Interview: We solicited each manager's general views on the differences between the PMF and CSMF (see Annex 1 to see the information that was presented to each participant). The interview then proceeded to the structured section in order to compare the various characteristics of these posts: time spent on various activities, the manager's roles or functions, systems for co-ordinating with the manager, characteristics of problems posed by the post and solutions required, and characteristics of the conceptual frameworks used. The closed part of the interview was repeated on two occasions with two of the managers in order to check the consistency of the data. While interviews could not be recorded due to the nature

\footnotetext{
${ }^{1}$ Please contact the corresponding author for a copy of the interview script used in Study 2.
} 
of the posts held by participants, the research team thoughtfully compiled notes of all relevant aspects discussed during the interviews.

Analysis: A grounded theory approach (Glaser and Strauss, 1967) was followed to make sense of the evidence gathered within the interviews. The material was revised by two researchers and, rather than codifying it, we discussed the meaning of each case and its relevance in terms of the study's research question.

\section{Study 3: Surveying high-ranking members of the Basque Government}

For our third study we used a questionnaire to observe the same phenomenon from a different methodological perspective, overcoming the limitations of small direct observation samples, and providing greater scope for generalising the conclusions reached (Bailey, 1994).

We developed the questionnaire as part of a project commissioned by the Rationalisation and Modernisation Board (CORAME) comprising high-ranking members of the Basque government, all political appointees and senior civil servants (IGDP-ESADE, 1994). The questionnaire was designed as a diagnostic tool for revealing the characteristics of managers' work and the rules for dividing and coordinating work between and within departments, units and hierarchical levels. The questions aimed to measure organisational variables strongly related to efficacy and efficiency in public administrations (IDGP-ESADE, 1994).

Questions: The questionnaire contained three distinct parts. The first contained questions regarding the nature of the manager's work. This section was followed by another group of questions targeting the organisation and the work of the manager's organisational unit. Finally, last segment of the questionnaire focused on the 
relationships between the manager's unit and others within the organisation (e.g. the department, other government departments, and other public administrations) ${ }^{2}$.

Sample and Distribution Procedure: The researchers worked with the Vice President's Department of the Basque Government to draw up a list of possible questionnaire recipients. Initially, the questionnaire was focused on Under Secretaries, Directors, Deputies (all of them politically-appointed) and other top civil servants (level 28-30 in the Basque-Spanish civil service system). A total sample of 290 was identified and contacted.

In order to distribute the questionnaires, we followed a progressive distribution by departments of the Basque Government. Initially, the Vice Presidents sent contact letters to senior members of the coalition government (the Basque government was then a coalition between Nationalists and Socialists) describing the purpose of our study and asking for their collaboration. After this initial contact, a member of the research group contacted all identified questionnaire recipients, explaining the purpose of the study and asking for their co-operation. Those employees who agreed to take part in the study were then invited to a face to face session with a research member in order to complete the questionnaire. Due to the nature of this study, we decided to handle the questionnaire in person to be able to discuss with each recipient each of the questionnaire items and ensure that all respondents understood all of our questions. Hence, a brief five minute explanation was given to recipients, and the resolution of queries and support as necessary. After this, they were informed that the timescale for completion was one week. In addition, a telephone call was made five days after distributing the questionnaire and an appointment made to collect the

\footnotetext{
${ }^{2}$ Please contact the corresponding author to receive a copy of the full questionnaire used in this study.
} 
completed form. Finally, a total number of 230 questionnaires was gathered $(79.3 \%$ response rate).

Analysis: Forty-one questions directly related with management function were selected from the 119 in the questionnaire. Fourteen were related to the type of work, 20 to organisational variables, and ten to managers' behavioural relationships with their units.

The first step was to analyse whether answers to the selected questions revealed differences in the behaviour of political managers vis-à-vis those from the Civil Service. A null hypothesis was employed which postulated that answers were independent of the kind of post involved. A Test of the Independence of characteristics was employed to establish whether the hypothesis was statistically supported so the null hypothesis was rejected, due to the categorical nature of the variables. The alpha value was set at 5\% for Pearson's Chi-squared test. Rejection of the null hypothesis would lead to the inference that the Political or Civil Service nature of the post influenced questionnaire responses. Table 2 shows the questions used to characterise political and Civil Service manager functions, together with the results of the Pearson's Chi-squared test comparing both posts.

[-Insert table 2 about here-]

\section{Results}

In this section, we compile the information gathered in each of the three studies and develop the results, focusing on each individual hypothesis.

\section{Hypothesis 1}

Our first hypothesis states that the liaison role carries greater weight (in terms of time spent on it and importance) for the PMF than for the CSMF. The descriptive statistics used in each study referring to this hypothesis are shown in Table 3. 
[-Insert table 3 about here-]

Observations of managers supervising a horizontal function (personnel, financial management, co-ordinating government function, etc.) revealed that considerable time is spent on this role (i.e. 3.6, 4.4, 5.7 and 3.5 hours per day).

When comparing the number of departmental committees attended by both PMF and CSMF, and in which leaders can communicate with both internal and external members of their organisations, the survey results show that political managers participate in more committees with other administrations than civil service managers do: $X^{2}(8, N=190)=15.23, p=.05$. Similarly, PMF also participate on more committees with other administrations than CSMF: $X^{2}(6, N=171)=14.54, p$ $=.02$.

During the interviews, one of the General Directors interviewed stated: “... when I was appointed Director General [political position] everybody wanted to have meeting with me, and I was invited to participate in an insanely large number of committees; while when I was Director General Deputy [civil service position] only the members of my team held meetings with me on a weekly basis: when acting as a Director General, I thought that someone had introduced a magnet in my body during the appointment process ...”.

The expression of this interviewee reflects the idea that the PMF is required to act as liaison much more than in the case of CSMF. In a similar vein, another politician that had previous experience as a high civil servant stated:

“... now (as a politician) I understand the difference between doying politics and behing a civil servant: the whole idea of networking is absolutely fundamental to develop political action. Before (as a civil 
servant) attending cocktails and receptions seemed a waist of my time.

Now I really need to attend them to meet somekey stakeholders tat I want to interact with...".

While the evidence collected from the survey study and interviews seem to support the hypothesis, during our observation and shadowing of politicians and senior public managers we noted two significant remarks: (1) the differences in dedication/time spent between both functions are not very large; (2) of the politicians observed, two displayed time and frequency values for roles that were similar to those obtained for civil service managers.

The second observation requires explanation if we are to justify the corroboration of Hypothesis 1. We observed that political managers supervise the whole organisation, which makes the internal aspect of the liaison role (i.e. the relations within the institution but beyond their units) irrelevant in this case. We noted that two elected officials spent a significant amount of time on internal activities and one of the politicians, a cabinet member, spent half of the observation day on an election campaign. The most important roles played were spokesperson and external leader. Another factor that should be taken into account was that the observation took place at the end of a term of office. This means that less time was spent on the horizontal co-ordination of activities and projects forming part of the job during rele on the observation day than would have been the case in an average day. The impending election represented a temporary factor inhibiting the liaison role.

\section{Hypothesis 2}

The spokesperson role refers to those leaders who represent and speak for their units. Before describing the insights revealed by each study referring to this hypothesis, 
Table 4 presents the descriptive statistics of those indicators considered for the hypothesis.

[-Insert table 4 about here-]

A good proxy by to understand the differences between PMF and CSMF is, again, through the number of inter-administrative committees in which they participate. As previously mentioned regarding the liaison role, the survey results show how PMF attend significantly more committees with other departments than CSMF: $X^{2}(6, N=$ $171)=14.54, p=.02$. However, what can help us to distinguish the type of spokesperson activities held by politicians and senior civil servants is their personal experience. In this sense, one of the interviewees reflected on the importance of the spokesperson role when developing a PMF by stating the following:

"Despite all my experience as a senior official, representing my department in many meetings, including international meetings, in my early days as mayor there was a fact that surprised me deeply: when I spoke, everyone thought that was my small town who spoke!".

In a similar vein, another politician interviewed stated that:

"If you do not like to represent a group of people and make public speaches as a leader of this group, do not get into politics and stay as a high civil servant. And if you decide to become a politician, you better learn how to address the audience because it is much more difficult than simply reciting a few prepared sentences".

Despite all our evidence corroborating Hypothesis 2, in some direct observation indicators the standard deviation was high. In fact, two of the elected political managers and one politically-appointed (i.e. not elected) one obtained similar marks to those obtained by the civil service managers, which renders the average obtained 
from observations meaningless in this case. A civil servant also exhibited behaviour similar to the political managers. An explanation of these data is needed if we are to validate the hypothesis. The two elected politicians were asked whether the day observed could be considered typical of their normal work. Their answers revealed that the day observed was a 'normal' day, but of the internal 'kind' with little outside contact. The response of the politically-appointed manager was along the same lines: the day observed involved preparation for meetings and trips for the following week. These factors reduced the frequency and time spent on the spokesperson role. In the case of the civil servant, the main part of the spokesperson role was internal to the institution due to the horizontal nature of the post. Given this, we consider that the hypothesis is supported.

\section{Hypothesis 3}

The external leader role carries greater weight (in terms of time spent on it and importance) for the PMF than CSMF. Table 5 displays the descriptive information of those indicators used to assess our third hypothesis.

[-Insert table 5 about here-]

The vast majority of the interviewed managers $(82 \%)$ considered that PMF devoted more time to external leadership activities when compared to CSMF. In the same vein, the same percentage of interviewees considered that developing external leadership roles was more important for the smooth running of the unit, or organisation in the case of PMF; different to CSMF. In this sense, one of the interviewees explained that:

"When I was head of my department [civil servant] I felt I was the leader of my team. As Regional Minister of Education I never had that feeling. 
I felt leading parents and people, a large community of citizens in the

common desire of having a better education for our country".

Our results from the direct observations corroborate these findings. On average, we observed 33 external leadership activities per day among PSF, while we discovered only these types of activities 11 times on average among CSMF.

We observed that the PMF in these cases was characterised by demands displaying the following features. First, the number of people involved in most demands is greater in the case of PMF posts than in CSMF ones. The number of people or groups involved in most demands is greater in the case of PMF posts than CSMF. Another politician interviewed exemplifies this by stating:

"I had attended a few seminars on how to lead a group of people and I did not found them to be very usefould. Lead your team is not the difficult part, what becomes a real challenge is to lead people that are outside your team!”.

In addition, the level of inter-relationships in most cases is greater in the case of PMF posts than in CSMF roles. Although this is not true of all the demands analysed: for example, when a civil servant is involved in, say, drafting legislation on tourism, he/she must "conceptually" deal with more people than the mayor who might simply have to decide how to pay for a sole contract. However, the PMF more frequently deals with demands involving more inter-relationships. It can therefore be said that this function is characterised by a greater number of inter-relationships overall. Finally, there also seems to be fewer precedents in the case of the PMF. Many of the subjects were entirely new to these political managers: they simply had no precedents to go on. This characteristic becomes less pronounced as political managers gain experience in the post. Nevertheless, the relative lack of precedents is a marked 
feature of this post (installation of new cell phone aerials, demands for housing for immigrants, etc.).

\section{Hypothesis 4}

The results regarding the weight of conceptualising roles between PMF and CSMF are less clear than with the other analysed ones. As the descriptive information presented in table 6 shows, when observing real managers, we distinguished on average 76 daily activities linked with conceptualiser roles for PMF, while for CSMF these occur less frequently at 58 times a day. While these differences are not vast, interviewees provided a clearer distinction.

[-Insert table 6 about here-]

For $73 \%$ of the interviewed managers, this role was more significant for PMF when compared with CSMF. The conceptual role not only refers to the very expression of this management orientation, but also reflects the characteristics of the demands and solutions observed during the first study of this research. The implications of such characteristics in the use of the conceptualiser role are clearly identified by the following statement from a former senior civil servant manager who was now a politician:

"As [a] politician, I feel the need to think far more than as senior civil servant: everything is more complex for me. And the implications of my decisions are greater. Most of the days I arrive at home exhausted. I even have problems understanding what my kids are telling me!"

Another participant with experience as both politician and high civil servant provided a similar quote:

"When I was a General Director (civil servnt post), most of the petitions and problems that I needed to solve where not new to me, I have faed 
them at some point in the past. When I become a politician, most of the problems where new, I had to learn, lisen a lot, think... In some occasions, I missed the automatisms, the intuition and the stability of a high civil servant post"”.

When observing politicians with management responsibilities, we saw how their demands involve a large number of actors and parties, also with more interrelationships among each of these actors and/or members. In addition, each solution that was implemented had fewer precedents when compared to those being operationalised among civil servant managers.

\section{Discussion and Conclusion}

By triangulating the data from three different studies, we have provided empirical evidence that core management roles developed by politicians differ from those developed by senior civil servants. While all managers at some point use all the management roles described by Mintzberg (1973, 1989, 1994, 2009), our results show how PMF and CSMF emphasise the use of certain roles above others. These differentiations seem to be rooted in the disparities between the demands made on both positions and the coordination systems needed. Our results corroborate previous studies elaborating on existing management differences between politicians and senior civil servants (Liguori, Sicilia and Steccolini, 2009; May and Winter, 2009), but also highlight several similarities between both types of management position.

Our research confirms that in the case of the PMF, liaison and spokesperson roles are of considerable importance compared with the CSMF and sample findings from other studies. Arguably, this is a result of demand characteristics, for example, numerous interrelationships with a lack of precedents and involving large numbers 
of people. The political manager can influence the environment in order to create a new vision (to which the CSMF has probably contributed). They can also perform the liaison and spokesperson roles, explore new ways of tackling demands/problems and create a political coalition that favours the adoption of the manager's proposals (or at least reduce opposition to them).

This seems to indicate that considerable conceptualising (with all the intellectual and monitoring skills this implies) is required. However, while the conceptualising role is greater for the PMF than the CSMF the difference is less than might be expected, given the demand characteristics and conceptual frameworks indicated above. In order to be more effective, those developing PMF should pay greater attention to the conceptualising role. This does not necessarily involve more time but would involve better or greater access to information to facilitate the creation of conceptual frameworks through networks, internal and external advice, etc.

It is worth emphasising the importance of the external leader in this context, as it is ignored by many management experts (Kurke and Aldrich, 1983; Mintzberg, 1994; Stewart, 1988): the PMF's fields of action embrace not only the organisational unit (ministry, department, etc.) but also a much wider social system. This means they exercise leadership in fields in which they have no formal authority (or if they do, it is not comparable to their authority within the organisation's hierarchy). To this, we should add the lack of off-the-peg technical solutions to society's demands. Political managers provide orientation and motivation, but also make societal actors take responsibility as a way of changing their perceptions and behaviour (Heifetz, 1995).

All manager roles can be observed in civil service posts and, through these, organisational units can perform traditional management functions. However, the distinctive features of demands/problems/solutions, conceptual frameworks and co- 
ordination mechanisms appear to place the emphasis on certain roles. Predictability of demand and the existence of precedents appear to exert considerable influence.

In addition, it seems that the specialisation found in larger organisations obliges civil service managers to exercise a liaison role within the organisation and establish links with other units from which co-operation is sought. The external facet of the CSMF requires a liaison role to create a network of links between interest groups. These groups are more organised than those dealt with by political managers, their relationship with the administration is more formalised, and their demands are more technical and/or strongly linked to practical aspects of public policy (Aberbach et al., 1981).

While the political manager's function mainly contributes to the drafting of policies and strategies and the creation of an environment conducive to carrying them out, the civil service management function seems to focus on improving management capabilities for policy implementation. This is in line with the traditional view that the civil service function is to administer. Nevertheless, we should not fall into the trap of simply terming this 'administration': the remit of senior civil service managers goes far beyond this. Civil service managers actively participate in formulating policy/strategy and exert a more definite liaison role to create the environment needed to carry out policies and strategies.

The results reported in this study have significant practical implications. First, the time and importance devoted to each role vary substantially according to post (political or civil service). In addition, the managerial work developed by each post should be clearly differentiated according to the roles developed by each post. These are especially relevant in systems where there is a tradition of some civil servants becoming politicians: awareness of these differences is crucial to avoid failure and 
improve the performance of both civil servant managers and politicians. These differences could strongly affect the HR policies currently being implemented across public administrations, especially those related to the selection, recruitment, evaluation and development of employees. The results reported in these three studies should be taken as a starting point to help differentiate the management boundaries between politicians and senior civil servants.

This study presents two major limitations. The first is that the three empirical studies were developed in Spain and may therefore be contingent on that country's institutional framework. It has been argued that the differentiation between politicians and managers is highly contingent to the country of analysis (Klausen and Magnier, 1998); however, recent empirical evidence shows little effect of managerial reform on the management roles of top civil servants (Bourgault and Van Dorpeon, 2013). Further research should analyse whether the results presented in this study can be generalised to other countries. The second limitation of this paper is that we have considered four specific managerial roles (liaison, spokesperson, external leader and conceptualiser). Mintzberg (1989) proposes ten different roles - there are several managerial activities that are not reflected within the roles we selected. Therefore, future research is needed in order to understand whether the managerial roles of politicians and senior civil servants present significant differences within other administrative traditions and when other managerial behaviours are analysed. Only by developing more studies addressing how management is extended by both politicians and civil servants, will we be able to understand how to distinguish and complement the managerial responsibilities of each post.

\section{References}


Aberbach, JD., Putman, R. and B., Rockman. 1981. Bureaucrats and Politicians in Western Democracies. Cambridge, MA: Harvard University Press.

Aberbach, JD. and BA., Rockman. 1988. "Image IV Revisited: Executive and Political Roles." Governance 1(1): 1-25.

Aberbach, JD. and BA., Rockman. 2006. "The Past and Future of Political Administrative Relations: Research from Bureaucrats and Politicians to In the Web of Politics - and Beyond." International Journal of Public Administration, 29, 977-995.

Allan, P. 1981. "Managers at Work: A Large-Scale Study of the Managerial Job in New York City Government.” The Academy of Management Journal, 24, 613619.

Ammons, D. and C., Newell. 1989. City Executives. Albany: State University of New York Press.

Bäck, H., Heinelt, H. and A., Magnier. 2006. The European Mayor: Political Leaders in the Changing Context of Local Democracy. VS Verlag.

Badaracco, J. 2002. Leading Quietly: An Unorthodox Guide to Doing the Right Thing. Harvard Business Press.

Bailey, K.D. 1994. Methods of Social Research $\left(4^{\text {th }}\right.$ ed. $)$. New York: The Free Press.

Barcelona, J. 1991. Principio de Legalidad y Organización Administrativa. Madrid: Civitas.

Bourgault, J. and K., Van Dorpe. 2013. "Managerial Reforms, Public Service Bargains and Top Civil Servant Identity." International Review of Administrative Sciences, 79, 49-70. 
Christensen, T. and P., Lægreid. 2012. "Competing Principles of Agency

Organisation - The Reorganisation of a Reform." International Review of Administrative Sciences, 78, 579-596.

Creswell, W. J. 2013. Qualitative Inquiry and Research Design: Choosing Among Five Approaches. Sage Publications.

Demir, T. and RC., Nyhan. 2008. "The Politics Administration Dichotomy: An Empirical Search for Correspondence between Theory and Practice." Public Administration Review, 68, 81-96.

Denzin, NK. 1978. The Research Act: A Theoretical Introduction to Sociological Methods. New York: McGraw-Hill.

Duignan P. 1980. “Administration Behaviour of School Superintendents: A Descriptive Study.” Journal of Educational Administration, 28, 5-26.

Eisenhardt, KM. and ME., Graebner. 2007. "Theory Building from cases: Opportunities and Challenges." Academy of Management Journal, 50, 25-32.

Eskridge, R. 2014. “Understanding CEO Time Perception and Time Usage: Are New Municipal Typologies Useful?” Public Administration Research, 3, 52-67. Feilders, JF. 1979. Action and Reaction: The Job of an Urban Superintendent. Unpublished dissertation, Stanford University.

Glaser, BG. and AL., Strauss. 1967. The Discovery of Grounded Theory: Strategies for Qualitative Research. Chicago, Aldine Publishing Company

Hansen, JR. and AR., Villadsen. 2010. “Comparing Public and Private Managers' Leadership Styles: Understanding the Role of Job Context." International Public Management Journal, 13, 247-274.

Heifetz, RA. 1995. Leadership without Easy Answers. 5th ed. Cambridge, MA: The Belknap Press of Harvard University Press. 
IDGP-ESADE. 1994. Estudio para la CORAME Gobierno Vasco. Barcelona:

ESADE-Instituto de Dirección y Gestión Pública.

Jacobsen, DI. 2006. "The Relationship between Politics and Administration: The Importance of Contingency Factors, Formal Structure, Demography, and Time." Governance, 19, 303-323.

Jick, TD. 1979. "Mixing Qualitative and Quantitative Methods: Triangulation in Action.” Administrative Science Quarterly, 24, 602-611.

Kammerer, GM. 1964. "Role Diversity of City Managers.” Administrative Science Quarterly, 8, 421-442.

Kaplan, A. 1998. The Conduct of Inquiry. Methodology for Behavioral Science.

New Brunswick, NJ: Transaction Publishers.

Klausen, K.K. and A., Magnier. 1998. The Anonymous Leader: Appointed CEOs in Western Local Government. Odense: Odense University Press.

Konrad, AM., Kashlak R., Yoshioka I., Waryszak R., and N., Toren. 2001. "What Do Managers Like to Do? A five-country study.” Group Organisation Management, 26, 401-433.

Kotter, JP. 1988. The Leadership Factor Vol. 10. New York: Free Press.

Kotter, JP. 1999. John P. Kotter on What Leaders Really Do. Harvard Business Press.

Kurke, LB. and HE., Aldrich 1983. "Mintzberg Was Right! A Replication and Extension of the Nature of Managerial Work.” Managerial Science, 29, 975984.

Liguori, M., Sicilia, M. and I. Steccolini. 2009. "Politicians Versus Managers: Roles and Interactions in Accounting Cycles." International Journal of Public Sector Management, 22, 310-323. 
Losada, C. 2008. Liderar en el Ámbito Público. Los Escenarios de la Gestión Pública del Siglo XXI. Escuela de Administración Pública de Catalunya. Martinko, MJ. and W., Gardner. 1990. "Structured Observation of Managerial Work: A Replication and Synthesis.” Journal of Management Studies, 27, 329357.

Mason, J. 1996. Qualitative Researching. London: Sage.

May, PJ. and SC., Winter. 2009. "Politicians, Managers, and Street-Level Bureaucrats: Influences on Policy Implementation.” Journal of Public Administration Research and Theory, 19, 453-476.

Mervis, CB. and JR., Pani. 1980. "Acquisition of Basic Object Categories." Cognitive Psychology, 12, 496-522.

Metcalfe, L. 1993. Public Management: from Imitation to Innovation. In: Kooiman J Ed. Modern Governance: New Government-Society Interaction. London: Sage.

Mintzberg, H. 1973. The Nature of Managerial Work. New York: Harper and Row. Mintzberg, H. 1989. Mintzberg on Management: Inside our Strange World of Organisations. New York: The Free Press.

Mintzberg H. 1994. "Rounding Out the Manager's Job.” Sloan Management Review, 94, 11-26.

Mintzberg, H. 1997. Managing on the Edges. International Journal of Public Sector Management, 10, 131-153.

Mintzberg, H. 2009. Managing. San Francisco: Berret- Koehler Publishers, Inc. Mount, DJ. and Al., Barlett. 1999. “The Managerial Role Assessment Survey: Design and Test of an Instrument Measuring Mintzberg's Roles among Hotel Managers.” Journal of Hospitality \& Tourism Research, 23, 160-175. 
Mouritzen, PE. and JH., Svara. 2002. Leadership at the Apex: Politicians and Administrators in Western Local Governments. Pittsburgh: University of Pittsburgh Press.

Mussari, R. 1994. “Accounting and Accountability in Italian Local Governments: Recent Changes and Challenges for the Future.” Public Budgeting \& Finance, $14,54-70$.

Noordegraaf, M. 2000. "Professional Sense-Makers: Managerial Competencies Amidst Ambiguity." International Journal of Public Sector Management, 13, 319-332.

Nutt, P. 2006. "Comparing Public and Private Sector Decision-Making Practices." Journal of Public Administration Research and Theory, 16, 289-318.

Pavett, CM. and AW., Lau. 1983. "Managerial Work: The Influence of Hierarchical Level and Functional Specialty." The Academy of Management Journal, 26, $170-177$.

Pitner, NJ. 1978. Descriptive Study of the Everyday Activities of Suburban School Superintendents: The Management of Information. Doctoral dissertation, Ohio State University.

Poole, M., R. Mansfield, and J. Gould-Williams. 2006. "Public and Private Sector Managers Over 20 Years: A Test of the 'Convergence Thesis'.” Public Administration, 84, 1051-1076.

Rainey, HG. 1989. "Public Management: Recent Research on the Political Context and Managerial Roles, Structures, and Behaviors." Journal of Management, 15, 229-250. 
Riba, C. 1993. El Método Observacional. Decisiobes Básicas y Objetivos. In: Anguera MT Ed. Metodología Observacional en la Investigación Psicológica. Barcelona: PPU, pp.29-114.

Sayles, LR. 1993. The Working Leader. NY: The Free Press.

Snyder, N. and WF., Glueck. 1980. "How Managers Plan. The Analysis of Managers' Activities.” Long Range Planning, 13, 70-76.

Stewart, R. 1988. Managers and Their Jobs. 2nd ed. London: Macmillan Press.

Svara, JH. 1999. "Complementarity of Politics and Administration as a Legitimate Alternative to the Dichotomy Model.” Administration \& Society, 30, 676-705.

Svara, JH. 2001. "The Myth of the Dichotomy: Complementarity of Politics and Administration in the Past and the Future of Public Administration." Public Administration Review, 61, 176-183.

Svara, JH. 2006. "The Search for Meaning in Political-Administrative Relations in Local Government.” International Journal of Public Administration, 29, 10651090.

Thompson, F.J. 1979. "Professionalism, Mistrust of Politicians and the Receptivity of Civil Servants to Procedural Buffers: The Case of Personnel Officials." The American Review of Public Administration, 13, 143-156.

Visauta, B. 1989. Técnicas de Investigación Social. Barcelona: PPU. 


\section{Tables and Figures}

\section{Table 1. Sample of Individuals Interviewed}

\begin{tabular}{|l|l|}
\hline SYSTEM OF ACCESS TO THE & $\begin{array}{l}\text { (The number of cases forming the subject of interviews and } \\
\text { the kind of administration involved is shown in brackets) }\end{array}$ \\
\hline Direct election by citizens & Mayor (1) (Local) \\
\hline Political nominee (member of & Minister (1) (State government) \\
Government) & Minister (1) (Regional government) \\
& Councillor (1) (Local government) \\
\hline Political nominee (non-member of & Secretary of State (1) (State government) \\
Government) & Deputy Secretary of State (4) (State government) \\
& Secretary General (1) (State government) \\
& Director General (5) (State government) \\
& Secretary General (5) (Regional government, Catalonia) \\
& Secretary General (8) (Regional government, Catalonia) \\
& Deputy Ombudsman (1) (Regional government, Catalonia) \\
& Director (2) (Local government) \\
& Area Director (2) (Local government) \\
\hline Free designation from civil & Divisional Head (1) (International organizational) \\
servants & Deputy Director General (8) (State government) \\
& Deputy Director General (10) (Regional government) \\
& Service Director (1) (Local government) \\
\hline Access systems based on merit & Council Secretary (1) (Local government) \\
& Head of unit (3) (Local government) \\
& Business Manager (3) (Local government) \\
& Head of Service (6) (Regional government) \\
\hline
\end{tabular}

Table 2: Questions used in Study 3 to distinguish the managerial roles of the PMF and the CSMF.

\begin{tabular}{|l|l|l|}
\hline Item & Question & $\begin{array}{l}\text { Pearson's } \\
\text { Chi-squared } \\
\text { test }\end{array}$ \\
\hline 6 & $\begin{array}{l}\text { How much of your time do you spend managing, planning or } \\
\text { supervising the work of your subordinates? }\end{array}$ & $\chi^{2}=.000$ \\
\hline 10 & $\begin{array}{l}\text { How clear are the objectives you are required to reach within a } \\
\text { given time frame? }\end{array}$ & $\chi^{2}=.001$ \\
\hline 17 & Has the Basque Government given you any job training? & $\chi^{2}=.000$ \\
\hline 19 & How many committees have you participated in? & $\chi^{2}=.055$ \\
\hline 35 & To what extent are you satisfied with each of the following factors? & \\
\hline $35 \mathrm{e}$ & The way work is organized in your department & $\chi^{2}=.039$ \\
\hline $35 \mathrm{k}$ & Society's image of Basque administration & $\chi^{2}=.025$ \\
\hline 351 & Knowledge of the government's priorities and strategies & $\chi^{2}=.000$ \\
\hline 43 & $\begin{array}{l}\text { Who takes the most important decisions concerning the functions of } \\
\text { your organizational unit? }\end{array}$ & $\chi^{2}=.044$ \\
\hline 48 & To what extent are objectives put down in writing? & $\chi^{2}=.002$ \\
\hline
\end{tabular}




\begin{tabular}{|l|l|l|}
\hline $55 \mathrm{a}$ & $\begin{array}{l}\text { Do your subordinates periodically report to you in writing on the } \\
\text { activities of the unit and the functioning of services? }\end{array}$ & $\chi^{2}=.003$ \\
\hline 63 & $\begin{array}{l}\text { To what extent does job description respond to the unit's present } \\
\text { needs? }\end{array}$ & $\chi^{2}=.044$ \\
\hline 68 & $\begin{array}{l}\text { To what extent is the work required of the unit set out in rules, } \\
\text { norms and procedural standards? }\end{array}$ & $\chi^{2}=.010$ \\
\hline 73 & $\begin{array}{l}\text { How many times have you sent memoranda or written reports } \\
\text { during the last three months in co-ordinating the work of your unit? }\end{array}$ & $\left(\chi^{2}=0,006\right)$ \\
\hline 74 & $\begin{array}{l}\text { How many times have you held periodic planning meetings with all } \\
\text { your immediate subordinates in the last three months? }\end{array}$ & $\left(\chi^{2}=0,004\right)$ \\
\hline 75 & $\begin{array}{l}\text { How many times have you had to hold unplanned meetings with } \\
\text { your immediate subordinates in the last three months in order to } \\
\text { resolve unforeseen problems? }\end{array}$ & $\left(\chi^{2}=0,002\right)$ \\
\hline
\end{tabular}

Table 3: Descriptive Indicator Values for Hypothesis 1.

SOURCE-INDICATOR

PMF SD CSMF SD

\begin{tabular}{|c|c|c|c|c|}
\hline \multicolumn{5}{|l|}{ Direct observation } \\
\hline Absolute frequency of liaison role & $\begin{array}{l}26 \text { times a } \\
\text { day }\end{array}$ & 8.2 & $\begin{array}{c}22 \\
\text { times a } \\
\text { day }\end{array}$ & 9.5 \\
\hline Relative frequency of liaison role ${ }^{3}$ & $26 \%$ & 9 & $23 \%$ & 8 \\
\hline Time spent on liaison role per day on average & $\begin{array}{l}3 \text { hours a } \\
\text { day }\end{array}$ & .8 & $\begin{array}{c}2.7 \\
\text { hours a } \\
\text { day }^{4}\end{array}$ & 1.3 \\
\hline $\begin{array}{l}\text { Percentage of time spent on relationships with people } \\
\text { outside the unit (excluding immediate boss and 'others' } \\
\text { category) }\end{array}$ & $38.4 \%$ & & $25 \%$ & \\
\hline \multicolumn{5}{|l|}{ Interview } \\
\hline More time is spend on the liason role for: & $\begin{array}{l}79 \% \\
(.33)\end{array}$ & .23 & $9 \%$ & \\
\hline $\begin{array}{l}\text { The liason role is more important for the smooth running } \\
\text { of the unit in the case of: }\end{array}$ & $\begin{array}{l}67 \% \\
(.36)\end{array}$ & .26 & $12 \%$ & \\
\hline \multicolumn{5}{|l|}{ Questionnaire } \\
\hline Number of committees within their department (internal) & 1.65 & nd & 1.08 & n.d. \\
\hline Number of other administrations' committees (external) & 1.78 & nd & .77 & n.d. \\
\hline
\end{tabular}

\footnotetext{
${ }^{3}$ Percentage of total behavioural units observed categorised as liaison role. It must be noted that some behavioural units could be categorised in more than one role.

${ }^{4}$ The percentage of time spent on this role is somewhat higher in the case of the CSMF (13\% versus $17 \%)$. The total work hours per day are greater in the case of the PMF because political managers put in longer working days.
} 
Table 4: Descriptive Indicator Values for Hypothesis 2.

SOURCE-INDICATOR

PMF SD CSMF SD

\begin{tabular}{|c|c|c|c|c|}
\hline \multicolumn{5}{|l|}{ Direct observation } \\
\hline Absolute frequency of spokesperson role & $\begin{array}{l}37 \text { times a } \\
\text { day }\end{array}$ & & $\begin{array}{c}24.8 \\
\text { times a } \\
\text { day }\end{array}$ & \\
\hline Relative frequency of spokesperson role ${ }^{5}$ & $33 \%$ & 10 & $26 \%$ & 9 \\
\hline Time spent on spokesperson role per day on average & 2.6 hours & 1.4 & 2 hours & .7 \\
\hline \multicolumn{5}{|l|}{ Interviews } \\
\hline More time is spend on the spokesperson role for: & $\begin{array}{l}85 \% \\
(.30)\end{array}$ & .23 & $6 \%$ & \\
\hline $\begin{array}{l}\text { The spokesperson role is more important for the smooth } \\
\text { running of the unit in the case of: }\end{array}$ & $\begin{array}{l}82 \% \\
(.28)\end{array}$ & .25 & $15 \%$ & \\
\hline \multicolumn{5}{|l|}{ Questionnaire } \\
\hline Number of other administrations' committees (external) & 1.78 & nd & .77 & nd \\
\hline Number of committees within their department (internal) & 1.65 & nd & 1.08 & nd \\
\hline
\end{tabular}

Table 5: Descriptive Indicator Values for Hypothesis 3.

PMF SD CSMF SD

SOURCE-INDICATOR

\begin{tabular}{|l|c|c|c|c|}
\hline Direct observation & $\begin{array}{c}33 \text { times a } \\
\text { day }\end{array}$ & $\begin{array}{c}11 \\
\text { times a } \\
\text { day }\end{array}$ & \\
\hline Absolute frequency of external leader role & $30 \%$ & 4.5 & $11 \%$ & 8.8 \\
\hline Relative frequency of external leader role & 3.1 hours & 1.4 & $\begin{array}{c}1.1 \\
\text { hours }\end{array}$ & .9 \\
\hline Time spent on external leader role per day on average & $\begin{array}{l}82 \% \\
(.29)\end{array}$ & .26 & $12 \%$ & \\
\hline Interviews & $\begin{array}{c}82 \% \\
(.26)\end{array}$ & .23 & $9 \%$ & \\
\hline More time is spend on the external leader role for: & $\begin{array}{l}\text { The external leader role is more important for the smooth } \\
\text { running of the unit in the case of: }\end{array}$
\end{tabular}

\footnotetext{
${ }^{5}$ Percentage of total behavioural units observed categorised as spokesperson role. It must be noted that some behavioural units could be categorised in more than one role.

${ }^{6}$ Percentage of total behavioural units observed categorised as external leader role. It must be noted that some behavioural units could be categorised in more than one role.

${ }^{7}$ Only one civil servant (F1) performed this role to a similar extent to that found in politicians. This is because horizontal supervision of minor administrative conflicts produced greater exercise of the leadership role (based on role as expert) than would probably be found under normal circumstances.
} 
Table 6: Descriptive Indicator Values for Hypothesis 4.

PMF SD CSMF SD

SOURCE-INDICATOR

\begin{tabular}{|c|c|c|c|c|}
\hline \multicolumn{5}{|l|}{ Direct observation } \\
\hline Absolute frequency of conceptualising role & $\begin{array}{l}76 \text { times a } \\
\text { day }\end{array}$ & & $\begin{array}{c}58 \\
\text { times a } \\
\text { day }\end{array}$ & \\
\hline Relative frequency of conceptualising role ${ }^{8}$ & $72 \%{ }^{9}$ & 3.5 & $62 \%$ & 7.5 \\
\hline Time spent on conceptualising role per day on average & 3 hours & 6 & $\begin{array}{c}2.5 \\
\text { hours }\end{array}$ & 0.4 \\
\hline Co-ordination system most used with the post holder & \multicolumn{2}{|c|}{ Ad hoc } & \multicolumn{2}{|c|}{$\begin{array}{c}\text { Direct } \\
\text { supervision. } \\
\text { Skills. } \\
\text { Standardisation } \\
\text { of procedures. }\end{array}$} \\
\hline Characteristics of demands/solutions observed & \multicolumn{2}{|c|}{$\begin{array}{l}\text { More parties } \\
\text { involved. } \\
\text { More } \\
\text { interrelationships. } \\
\text { Fewer precedents. }\end{array}$} & \multicolumn{2}{|c|}{\begin{tabular}{|l|} 
Fewer parties \\
involved. \\
Fewer \\
interrelation- \\
-ships. \\
More \\
precedents.
\end{tabular}} \\
\hline \multicolumn{5}{|l|}{ Interviews } \\
\hline More time is spent on the conceptualizer role for: & $\begin{array}{l}73 \% \\
(.35)\end{array}$ & .23 & $12 \%$ & \\
\hline $\begin{array}{l}\text { The conceptualizer role is more important for the } \\
\text { smooth running of the unit in the case of: }\end{array}$ & $\begin{array}{l}76 \% \\
(.33)\end{array}$ & .22 & $9 \%$ & \\
\hline The conceptual framework is vaguer for: & $\begin{array}{l}85 \% \\
(.26)\end{array}$ & .24 & $15 \%$ & \\
\hline Managerial room for manoeuvre is greater for: & $\begin{array}{l}85 \% \\
(.30)\end{array}$ & .29 & $12 \%$ & \\
\hline $\begin{array}{l}\text { Direct supervision. The organisation could place more } \\
\text { trust in this system for co-ordinating the post-holder's } \\
\text { behaviour in the case of: }\end{array}$ & $18 \%$ & & $\begin{array}{l}70 \% \\
(.66)\end{array}$ & .31 \\
\hline $\begin{array}{l}\text { Standardisation of procedures. The organisation could } \\
\text { place more trust in this system for co-ordinating the } \\
\text { post-holder's behaviour in the case of: }\end{array}$ & $12 \%$ & & $\begin{array}{l}73 \% \\
(.75)\end{array}$ & .22 \\
\hline $\begin{array}{l}\text { Professional skills. The organisation could place more } \\
\text { trust in this system for co-ordinating the post holder's } \\
\text { behaviour in the case of: }\end{array}$ & $\begin{array}{l}42 \% \\
(.54)\end{array}$ & .30 & $39 \%$ & \\
\hline $\begin{array}{l}\text { Standardisation of values (personal trust): The } \\
\text { organisation could place more trust in this system for co- } \\
\text { ordinating the post-holder's behaviour in the case of: }\end{array}$ & $\begin{array}{l}67 \% \\
(.34)\end{array}$ & .25 & $6 \%$ & \\
\hline $\begin{array}{l}\text { Standardisation of objectives. The organisation could } \\
\text { place more trust in this system for co-ordinating the } \\
\text { post-holder's behaviour in the case of: }\end{array}$ & $\begin{array}{l}64 \% \\
(.44)\end{array}$ & .34 & $24 \%$ & \\
\hline $\begin{array}{l}\text { Ad hoc systems. The organisation could place more trust } \\
\text { in this system for co-ordinating the post-holder's } \\
\text { behaviour in the case of: }\end{array}$ & $\begin{array}{l}61 \% \\
(.39)\end{array}$ & .33 & $21 \%$ & \\
\hline
\end{tabular}

${ }^{8}$ Percentage of total behavioural units observed categorised as conceptualising role. It must be noted that some behavioural units could be categorised in more than one role.

${ }^{9}$ The political-professional managers showed different behaviour: a relative frequency of $50.1 \%$ and time spent of 2.5 hours. 


\begin{tabular}{|c|c|c|c|c|}
\hline $\begin{array}{l}\text { The demands/solutions had more stakeholders involved } \\
\text { in the case of: }\end{array}$ & $\begin{array}{l}94 \% \\
(.19)\end{array}$ & .17 & $3 \%$ & \\
\hline $\begin{array}{l}\text { The demands/solutions is more critical for the } \\
\text { stakeholders in the case of: }\end{array}$ & $\begin{array}{l}70 \% \\
(.29)\end{array}$ & .29 & $15 \%$ & \\
\hline $\begin{array}{l}\text { The level of disagreement between those involved is } \\
\text { greater in the case of: }\end{array}$ & $\begin{array}{l}70 \% \\
(.36)\end{array}$ & .33 & $27 \%$ & \\
\hline $\begin{array}{l}\text { The number of interrelationships is greater in the case } \\
\text { of: }\end{array}$ & $\begin{array}{l}79 \% \\
(.29)\end{array}$ & .25 & $15 \%$ & \\
\hline $\begin{array}{l}\text { The likelihood of changes in demands is greater in the } \\
\text { case of: }\end{array}$ & $\begin{array}{l}73 \% \\
(.30)\end{array}$ & .27 & $18 \%$ & \\
\hline $\begin{array}{l}\text { The predictability of these changes in demands is less in } \\
\text { the case of: }\end{array}$ & $42 \%$ & & $\begin{array}{l}45 \% \\
(.56)\end{array}$ & .30 \\
\hline There are more precedents in the case of: & $27 \%$ & & $\begin{array}{l}67 \% \\
(.72)\end{array}$ & .26 \\
\hline
\end{tabular}


Exhibit 1: Examinning the daily tasks of politicians and high level civil servants.

Politician A

- Management of the calendar for the constitution of a new parliament and the process of appointing the Speaker.

- $\quad$ Amendments to the Environment Act (national legislation).

- Management of appointments to the Boards of Directors of publicly-owned companies.

- Collective bargaining in a publicly-owned television corporation

- Political acts regarding the concession of an historic building.

- $\quad$ Problems related to the constitution of a Civil Service body

- Negotiations for deciding the composition of the new government

- $\quad$ Lobbying in the Vatican regarding a church museum collection

Politician B

- $\quad$ Supervising public works (road junction, ring road, by-pass, etc.) which does not meet planned needs.

- Controversy over pollution of an aquifer.

- $\quad$ Potential legal action against a gas utility company for failure to comply with the terms of a contract.

- Start up of a telephone and web site system for providing better administrative services to citizens.

- $\quad$ Drafting and approval of Environmental Regulations.

- $\quad$ Project for automating the list of municipal residents

- Town planning conflicts

- Promotion of an industrial estate

- $\quad$ Defending municipal interests before the Tourist Industry

Civil Servant

- Application/adaptation of selection procedures to particular posts.

- $\quad$ Negotiations with trade unionists regarding alternative labour contractual arrangements.

- Monitoring workers'sick leave.

- Organizing short listing following interviews of candidates in a selection procedure.

- Dealing with a union complaint following lack of prior consultation regarding provision of training courses. 


\section{APPENDIX 1:}

This is the interview introduction that was presented to all participants:

"This interview forms part of a project that aims to identify differences between political and Civil Service management posts in the public sector. Various research techniques will be used for this purpose. One of these is the interview being conducted today.

We shall begin by asking for some information on the management work and functions you performed in your previous jobs in the public sector.

We shall first ask you questions concerning selected posts. One of these will be a political post and the other a Civil Service one. Both posts will be of a management nature (they may range from head of a unit to councillor or ministerial rank). If possible, the posts should have been held consecutively.

In second place, we are interested in your general perceptions regarding the differences between the two posts.

We hope to subsequently compare the following characteristics of these posts:

- time spent on activities

- manager's roles or functions

- the co-ordination systems employed

- characteristics of problems posed by the post and the solutions required

It is important that your answers be as accurate as possible."

\section{THANK YOU FOR YOUR PARTICIPATION}

